ISSN:2528-9527

E-ISSN : 2528-9535

YIl Year: 8

Cilt Volume: 9

Sayı Issue : 16

\title{
Psikoloji Eğitimi Alan Öğrencilerin Duygusal Zekâ ve Psikolojik Danışma Öz-Yeterliklerinin İncelenmesi
}

DOI: $10.26466 /$ opus. 460750

\author{
Mustafa Durmușçelebi $^{*}$ - Şaban Karayağız \\ *Doç. Dr. Erciyes Üniversitesi Eğitim Fakültesi Kayseri / Türkiye \\ E-Posta: mdcelebi@gmail.com \\ ORCID: 0000-0002-0325-7528 \\ * Dr. Öğretim Üyesi. Nuh Naci Yazgan Üniversitesi, Edebiyat Fakültesi Kayseri/ Türkiye \\ E-Posta: skarayagiz@nny.edu.tr \\ ORCID: 0000-0002-6914-4630
}

Öz

Öğrencilerin psikolojik danışma öz yeterlik ve duygusal zeka düzeylerini, aralarındaki ilişkiyi ve birbirlerini etkileme durumların tespit etmeye yönelik hazırlanan bu çalışmada tarama modeli kullaılmıştır. Bu çalışma, öğrenci görüşleri ele alınarak duygusal zekâ ve psikolojik öz-yeterlikleri arasındaki ilişki inceleyen betimsel bir çalışmadır. Çalışmanın örneklem grubunu Kayseri'de bulunan bir özel ve bir devlet üniversitesinin ilgili bölümlerinin 3 ve 4 . sinflarında okuyan toplam 394 ögrrenci oluşturmaktadır. Araştırmada very toplama aracı olarak Schutte ve arkadaşları (1998) tarafindan hazırlanıp Austin ve arkadaşları (2004) tarafından modifiye edilen Duygusal Zekâ Ölçeği ile Lent ve arkadaşları (2003) tarafindan geliştirilen Psikolojik Danışma Öz-Yeterlik Ölçeği kullanılmıştır. Araştırma sorularına paralel olarak istatistiksel sonuçlar (yüzde, frekans, ortalama vb.), değişkenler arasındaki ilişkileri ortaya çıarmak için korelasyon, bağımsız değişkenler arasındaki farkları tespit etmek amacıyla da t-testi ve f-testi kullanılmıştır. Öğrencilerin duygusal zekâ ile psikolojik danışma öz yeterlik ve alt boyutlarına ilişkin puanların betimlemek amacıyla yüzde, frekans ve ortalama gibi merkezi ölçüler kullanılmıştır. Öğrencilerin duygusal zekâ ve psikolojik danışma öz yeterlik düzeylerinin araştırmanın bağımsız değişikliklerine göre farklılıklarını belirlemek amactyla t- testi ve çoklu karşılaştırmalarda ise varyans analizi (f-testi), farkın kaynă̆ın belirlemek için LSD testi kullanılmıştır. Çalışmanın sonunda öğrenciler, duygusal zekâ ve psikolojik danışma öz yeterlik düzeylerinin iyi olduğunu belirtmişlerdir. Beklentilere paralel olarak, kadın öğrencilerin duygusal zeka düzeyi erkeklerden daha yüksek bulunmuştur. Toplam duygusal zeka ve alt boyutlarında PDR öğrencilerinin ortalamalarının Psikoloji bölümü öğrencilerinin ortalamalarından daha yüksek bulunmuştur. Öğrencilerin bölümlerini isteyerek seçip seçmemeleri, öğrenim gördükleri bölümden memnun olup olmamaları, hem duygusal zeka hem de psikolojik danışma özyeterlik düzeyi açısından belirleyici değişkenler olarak görülmektedir. Öğrencilerin duygusal zeka ve psikolojik danışma öz yeterlik düzeyleri arasında pozitif bir ilişki ortaya çıkmıştır.

Anahtar Kelimeler: Duygusal zeka, psikolojik danışma, öz yeterlik

OPUS @ C Uluslararası Toplum Araştırmaları Dergisi-International Journal of Society Researches ISSN:2528-9527 E-ISSN : 2528-9535

http://opusjournal.net 


\title{
Examination of Emotional Intelligence and Psycho- logical Counseling Self-Sufficiency of Psychology Education Students
}

*

\begin{abstract}
The purpose of this study was intended to investigate levels of self-efficacy, emotional intelligence, inter relationships between them and how they affect each other. This study, conducted according to survey approach, was a descriptive study in which the relationship between emotional intelligence and psychological self-efficacy was investigated in terms of students' views. The participants consisted of 394 college students enrolled in relevant departments at a private and a public university in Kayseri providence. They were in their senior and junior years at the time of data collection process. The Schutte Self-Report Emotional Intelligence Scale (SSEIT) initially developed by Schutte et al. (1998) and improved by Austin et al. (2004) and the Psychological Counselling SelfEfficacy Scale developed by Lent et al. (2003) were used to collect research data. In order to elaborate research questions, statistical results such as frequencies, percentages and means were analyzed to reveal relationships between variables (correlation). Also, $t$-test and f-test were used to determine differences between independent variables. Measures of central tendency including percentage, frequency, and mean scores were utilized to detail the students' responses on both scales and sub-dimensions. The t-test and was used to explore differences between self-efficacy levels of their emotional intelligence and psychological counselling. In addition, variance analysis (f-test) aimed to analyze multiple comparisons and LSD test to determine the source of differences. The findings revealed that the students expressed their self-efficacy levels of emotional intelligence and psychological counselling were exemplary. Aligned with the expectations, female students showed higher levels of emotional intelligence. The students of the Guidance and Counselling majors scored higher than psychology students in terms of emotional intelligence and its subscales. The factors, whether to choose their major purposefully and satisfaction levels with their majors were obtained as significant variables for both emotional intelligence and psychological counselling self-efficacy. There exists a positive relationship between emotional intelligence and self-efficacy levels of the students' psychological counselling.
\end{abstract}

Keywords: Emotional intelligence, psychological counseling, self-efficacy 


\section{Giriş}

Eğitim, toplum kültürünü nesilden nesile aktarmada önemli kurumlardan birisidir. Bu nedenle eğitim toplumsal alanda yaşanan gelişmelerden etkilenmektedir (Güçlü, 2017). Son 3 asırda ortaya çıkan sanayi devrimi ve teknolojik gelişmeler, günümüz toplumunu daha çok materyalist düşünmeye gerek iş yaşamında gerekse sivil yaşamda duygulardan uzak tamamen zihinsel temelli düşünmeye itmiştir. Günümüz dünyasında rekabet, tüketim, toplam kalite, yarışma, bilgi, zekâ vb. kavramları daha çok öne çıkarmıştır. İnsanlar giderek daha fazla tüketir hale gelmiş, tüketmek için de çılgın bir kazanma yarışına girilmiştir. Bu bağlamda üretim anlayışı değişmiş, bilgi ve teknolojinin baş döndürücü gelişimi üretilenin tüketilmesini de gerekli kılmıştır. 20. yüzyılın sonlarından itibaren özellikle akılcı zihin kullanılarak üretim yapmanın daha verimli olacağı düşünülmekteydi. Aslında bu iki zihin paralel olarak doğru kullanıldığında bize sağlıklı yaşama, kendimizi geliştirme, kaliteli yaşama ve pozitif düşünme konusunda yardımcı olurlar. Zaten gerek deneyimler gerekse yapılan araştırmalar (Caudran, 1999) bir süre sonra duygusal istekliliğin olmadığı, duygusal zihnin kullanılmadığı bir süreçte verimliliğin olmadığını da göstermiştir. Bu yüzden niceliğin yanı sıra nitelik konusu da artık gündeme gelir olmuştur. Ticarette dünyayı etkisi altına alan Çin hâkimiyeti buna örnek verilebilir. Şirketlerin yönetiminde verimlilik esas alınmış, çalışanlardan bu bağlamda en yüksek verim alınmaya çalışılmıştır. Bu amansız yarış içerisinde iş yaşamında sadece akılcı davranmanın, aklı kullanmanın tek başına verimi yükseltmeyeceği, duyguların da iş yaşamında işe koşulmasının verimi artıracağı anlaşılmıştır. Duygular örgütsel yaşamla iç içedir ve örgüt yaşamının ayrılmaz bir parçasıdır. Bu nedenle de çalışanların duygusal durumlarına daha fazla önem verilmesi gerektiğini vurgulamışlardır (Ashforth ve Humphrey, 1995). Hatta biraz daha ileri gidilerek, insanların hayattaki başarı ve mutluluğunun belirli bir entelektüel zekânın yanı sıra duygusal zekâya da sahip olmalarının gerekliliği ortaya atılmıştır. 


\section{Duygusal Zekâ}

2000'li yıllardan sonra duygusal zekâ kavramı gerek bilimsel çevrelerde gerekse iş dünyasında artan bir ilgiyle araştırma konusu olmuştur. Türkiye'de özellikle yöneticilerin duygusal zekâ boyutları (Ural, 2001), duygusal zekânın liderlik becerileriyle ilişkisi (Bülbüloğlu, 2001), duygusal zekânın başarı üzerindeki etkileri (Arıcıoğlu, 2002) üzerinde çalışmalar yapılmıştır. Yurt dışında yapılan çalışmalarda daha çok yönetim uygulamaları (Ashkanasy ve Daus, 2002), geliştirme programları içerisinde duygusal zekânın yeri (Schwarz, 2000) ve üniversitelerde özellikle öğretim programlarında duygusal zekânın ders olarak okutulması (Boyatzis, Stubbs, ve Taylor, 2002) üzerinde durulmuştur. Duygusal zekâ ilk kez Salovey ve Mayer tarafindan ortaya atılmış, bireyin kendi duygularını ifade edebilmesi, başkalarının duyguların izleyebilmesi, bunlar arasında ayırım yapabilmesi ve bu süreçte elde ettiği bilgileri düşünce ve davranışlarında kullanabilme, duygular ile bireysel süreçler arasında uyum sağlayabilmesi, duyguların farklı durumlar üzerindeki etkilerini anlayabilme şeklinde tanımlanmaktadır (Law, Wong, ve Song, 2004) (Salovey ve Mayer, 1990). Thorndike'in sosyal zekâ anlayışına dayanan (Planalp ve Fitness, 1999) duygusal zekâ, sosyal zekânın bir alt formu olarak tanımlanmaktadır (Salovey ve Mayer, 1990).

Duygusal zekâ kavramı, son on yıl içerisinde insan davranışları ve insan beyninin fonksiyonları üzerinde yapılan bilimsel araştırma verilerinin ışığında dünyada gittikçe artan bir ilgiyle kabul görmektedir.

\section{Psikolojik Danışma Öz-Yeterlikleri}

İlk kez Bandura'nın öğrenilen davranışların performansa dönüşebilmesi sürecini açıklamada kullandığı en önemli kavram olan öz yeterlik (SelfEfficacy), bireyin, belli bir performansı göstermek, olası durumlarla başa çıkabilmek için gerekli etkinlikleri organize edip, başarılı şekilde yapma yeteneğine dair yargısı olarak ifade edilmiştir (Bandura, 1986). Bireyler söz konusu öz yeterlik algılarını geçirdiği doğrudan ya da dolaylı deneyimlerle edinirler. Örneğin, bir işi başarılı şekilde tamamladıklarında bundan sonra da benzer işleri başarabileceklerine 
olan inançları yükselir, bunun tam tersi de mümkündür. Bir başkasının başardığı ya da başaramadığı işi gözlemek de dolaylı olarak kişinin öz yeterlik algısını değiştirebilir. Bandura (1986) bireyin öz yeterlik algısının kaynağını deneyimlerin yanı sıra sözel olarak ikna etme ve o işi yaparken kişinin hissettiği stres, korku ve heyecan gibi duygusal tepkilere de bağlamaktadır. Özetle öz yeterlik bireyin yaşadığı çevrede elde ettiği olumlu-olumsuz deneyimlerle ilgilidir.

Psikolojik danışma öz yeterliği, bireyin (danışmanın), danışanın taleplerini ne düzeyde karşıladığı ile ilgilidir. Danışmanın yeterliği, yardıma ihtiyacı olan danışana yaptığı yardımın etkililiği konusundaki algısı olarak düşünülebilir. Danışman öz yeterliğini danışmanın, danışma sürecinde danışmanlıkla ilgili davranışlar ve belirli klinik durumlarla baş edebilme konusunda kendi kapasitelerine ilişkin yeterlik algılarıdır (Larson \& Daniels, 1998). Psikolojik danışma yardımının birçok psikolojik problemin çözümünde etkili olduğunun kanıtlanmasıyla birlikte, bu yardımın etkililiğini arttıran faktörlerin neler olduğuna duyulan merak giderek artmıştır. Etkili bir psikolojik danışma sürecinin birçok bileşeni olmakla birlikte en önemli faktörlerden biri süreçte aktif bir rol üstlenen psikolojik danışmana ilişkin faktörlerdir. Alanda yapılan çalışmalar kaygı düzeyleri, anksiyete, performans, danışma ortamı vb. değişkenlerle öz yeterlik algıları üzerine yapılmıştır. Duygusal zekâ ile psikolojik danışma öz yeterlik arasındaki ilişkiyi inceleyen yeterli çalışma bulunamamıştır. Bireyin psikolojik danışma öz yeterlik düzeyi üzerinde duygusal zekânın etkisi de yine çalışılmamış konular arasındadır.

$\mathrm{Bu}$ çalışmanın amacı, Psikoloji ve PDR bölümü öğrencilerinin duygusal zekâ ve psikolojik danışma öz-yeterlikleri arasındaki ilişkinin incelenmesidir. Bu bağlamda araştırmada aşağıdaki sorulara cevap aranmıştır.

1. Öğrencilerinin duygusal zekâ ve psikolojik danışma öz-yeterlik düzeyleri nedir?

2. Öğrencilerin duygusal zekâ ve psikolojik danışma öz-yeterlik düzeyleri;

A) Cinsiyetlerine,

B) Öğrenim gördükleri bölüme, 
C) Öğrenim gördükleri bölümü isteyerek seçip seçmemelerine,

D) Öğrenim gördükleri bölümden memnuniyet düzeylerine,

E) Psikolojik yardım alıp almadıklarına göre anlamlı farklılık göstermekte midir?

3. Öğrencilerin duygusal zekâ puanları ile psikolojik danışma öz yeterlik puanları arasında anlamlı bir ilişki var mıdır?

4. Öğrencilerin psikolojik danışma öz yeterliklerini duygusal zeka düzeyleri hangi seviyede etkilemektedir?

\section{Yöntem}

\section{Araştırma Modeli}

Tarama modelinde yapılan bu çalışma, öğrenci görüşleri ele alınarak duygusal zekâ ve psikolojik öz-yeterlikleri arasındaki ilişki inceleyen betimsel bir çalışmadır.

\section{Evren ve Örneklem}

Çalışmanın evrenini PDR ve Psikoloji bölümlerinde okuyan öğrenciler oluşturmaktadır. Örneklem grubunu ise Kayseri'de bulunan bir özel ve bir devlet üniversitesinin ilgili bölümlerinde okuyan iki bölümün öğrencileri oluşturmaktadır. Öğrencilerin psikolojik danışma becerileri ve duygusal zekâ düzeylerinin en son düzeyini dikkate almak amacıyla çalışmaya sadece 3. ve 4. sınıflar dâhil edilmiştir. Öğrencilerin cinsiyet, bölüm ve sınıflarına göre dağılımına ilişkin bilgilere Tablo 1'de yer verilmiştir.

Tablo 1. Katılımcıların cinsiyet, bölüm ve sınıflarına göre dağılımı

\begin{tabular}{lllllll}
\hline \multirow{2}{*}{ Bölüm / Cinsiyet } & \multicolumn{2}{c}{ Kadın } & \multicolumn{3}{c}{ Erkek } & \multicolumn{3}{c}{ Toplam } \\
& $\mathrm{f}$ & $\%$ & $\mathrm{f}$ & $\%$ & $\mathrm{f}$ & $\%$ \\
\hline $\begin{array}{l}\text { Psikoloji } \\
\text { Psikolojik Danışmanlık }\end{array}$ & 235 & 81,6 & 53 & 18,4 & 288 & 59,9 \\
Rehberlik & 159 & 82,4 & 34 & 17,6 & 193 & 40,1 \\
& & & & & & \\
3. Sınıf & 268 & 83,2 & 54 & 16,8 & 322 & 66,9 \\
4. Sinıf & 126 & 79,2 & 33 & 20,8 & 159 & 33,1 \\
Toplam & 394 & 81,9 & 87 & 18,1 & 481 & 100,0 \\
\hline
\end{tabular}


Yukarıda verilen tabloda belirtildiği gibi, araştırmaya \%81,9'u kadın ve \%18,1'i erkek olmak üzere toplam 481 öğrenci katılmıştır. Bu öğrencilerin \%59,9'u Psikoloji ve \%40,1'i de Psikolojik Danışmanlık ve Rehberlik bölümü öğrencilerinden oluşmaktadır.

\section{Verilerin Toplanması}

Araştırmada veri toplamak amaciyla bir adet kişisel bilgi formu, duygusal zekâ ölçeği ve psikolojik danışma öz-yeterlik ölçekleri kullanılmıştır.

Duygusal Zekâ Ölçeği: Schutte ve diğerleri (1998) tarafından geliştirilen ve duygusal zekâ araştırmalarında yoğun olarak kullanılan 33 maddelik Duygusal Zekâ Ölçeği'nin kuramsal temeli 3 boyutlu duygusal zekâ modeline dayanmaktadır (Mayer ve Salovey, 1990). Austin ve diğerleri (2004) tarafından modifiye edilen Duygusal Zekâ Ölçeği, 20'si olumlu ve 21'i olumsuz toplam 41 maddeden oluşmaktadır. Austin ve diğerleri (2004) tarafından modifiye edilen bu ölçek, olumsuz maddelere daha fazla yer vermek için Schutte Duygusal Zekâ Ölçeği'nin bazı maddelerinin olumludan olumsuza çevrilmesi ve daha önceden güvenirliği diğer faktörlere göre daha düşük bulunan "Duygulardan Faydalanma" faktörünü temelde hedef alan bazı yeni maddelerin eklenmesiyle oluşmuştur. Ölçek, (1) kesinlikle katılmıyorum (2) katılmıyorum (3) kararsızım (4) katılıyorum ve (5) kesinlikle katılıyorum şeklinde 5'li Likert tipi bir derecelendirmeye sahiptir. Ölçek üç faktörden oluşmaktadır: İyimserlik/Ruh Halini Düzenleme (Optimism/Mood Regulation), Duygulardan Faydalanma (Utilisation of Emotions) ve Duyguların İfadesi (Appraisal and Expression of Emotions). Ölçek bu üç faktörü ve bütününde genel duygusal zekâyı ölçmektedir.

Araştırmanın bu bölümünde Orjinali Schutte ve diğerleri (1998) tarafından geliştirilmiş olan Duygusal Zekâ Ölçeği'nin (DZÖ) Austin ve diğerleri (2004) tarafından yeniden düzenlenmiş şeklinin Türkçeye uyarlama çalışmasına yer verilecektir. Araştırmacı ölçeğin Türkçe formunun geçerlik çalışmaları olarak yapı geçerliği, kapsam geçerliği, 
çeviri geçerliği ve uyum geçerliğini araştırmıştır. Ayrıca ölçeğin madde ayırt ediciliği için madde-test korelasyonu ve güvenirlik çalışmaları olarak test-tekrar test, iki yarı ve iç tutarlılık Cronbach $\alpha$ güvenirlik katsayıları belirlenmiştir. Ölçeğin geçerlik ve güvenirlik çalışmalarına ilişkin bulgular aşağıda verilmiştir (Göçet, 2006).

Psikolojik Danışma Öz-Yeterlik Ölçeği: Psikolojik danışman adaylarının psikolojik danışma öz-yeterlik düzeylerini ölçmek amacıyla Lent ve arkadaşları (2003) tarafından geliştirilmiştir. Ölçek, 3 faktör ve 41 maddeden oluşmaktadır. Yardım Becerileri Öz-yeterliği olarak adlandırılan ilk faktör 15 maddeden oluşmakta ve kendi içinde İçgörü, Keşif ve Eylem Becerileri olmak üzere üç alt boyuttan oluşmaktadır. Oturum Yönetmeye İlişkin Öz-yeterlik olarak adlandırılan ikinci faktör ise 10 maddeden oluşmaktadır. Üçüncü faktörü oluşturan Psikolojik Danışma Sürecindeki Zorluklara İlişkin Öz-yeterlik 16 maddeden oluşmaktadır. İlişkide Çatışmalar ve Danışan Problemleri olmak üzere iki alt boyutu bulunmaktadır. Cevaplama sistemi her ifade için (0) "hiç güvenmiyorum" ve (9) "tamamen güveniyorum" olarak onlu derecelendirme şeklindedir. Ölçekten alınabilecek en düşük puan " 0 " en yüksek puan 369'dur. Yüksek puanlar yüksek düzeyde psikolojik danışma öz-yeterliğini işaret etmektedir.

Ölçeğin orijinal formunun iç tutarlı̆̆ .97 olup, alt ölçekler için iç tutarlık katsayısının .79 ile. 94 arasında değiştiği sonucuna ulaşılmıştır. Ölçeğin benzer ölçek geçerliğini belirlemek amacıyla "Psikolojik Danışman Kendini Değerlendirme Ölçeği" (Larson ve ark., 1992) kullanılmış ve iki ölçeğin benzer alt ölçekleri arasında olumlu yönde yüksek ilişkiler olduğu görülmüştür. PDÖÖ’nün Türkçe’ye Çeviri Çalışması Ölçeğin Türkçe'ye uyarlanması aşamasında öncelikle ölçeği geliştiren araştırmacılardan biri olan R.W. Lent'ten ölçeğin Türkçe'ye uyarlanması için gerekli izinler alınmıştır. İlk olarak ölçek, Rehberlik ve Psikolojik Danışma alanında yüksek lisans yapmakta olan ve iyi derecede İngilizce bilen üç psikolojik danışman tarafından Türkçe'ye çevrilmiştir. Daha sonra ölçeğin Türkçe ve İngilizce formu, en uygun çevirilerin seçilmesi ve gerekli düzenlemelerin yapılması amacıyla Rehberlik ve Psikolojik Danışmanlık Anabilim Dalı'nda görev yapan ve en az doktora derecesine sahip üç öğretim üyesi tarafından incelenmiştir. 
Öğretim üyelerinin görüşleri 1şığında uygun görülen maddeler seçilerek Türkçe taslak form oluşturulmuştur. Oluşturulan taslak form Rehberlik ve Psikolojik Danışmanlık Anabilim Dalı'nda görev yapmakta olan farklı üç öğretim üyesine verilmiştir. Alınan geribildirimler doğrultusunda gerekli düzenlemeler yapılmıştır. Son olarak ölçeğin Türkçe formu bir alan uzmanı tarafından incelenmiş ve gerekli düzeltmeler yapılarak ölçeğe son hali verilmiştir. (Pamukçu ve Demir, 2013)

\section{Verilerin Analizi}

Araştırma sorularına paralel olarak istatistiksel sonuçlar (yüzde, frekans, ortalama vb.), değişkenler arasındaki ilişkileri ortaya çıkarmak için korelasyon, bağımsız değişkenler arasındaki farkları tespit etmek amacıyla da t-testi ve f-testi kullanılmıştır. Öğrencilerin duygusal zekâ ile psikolojik danışma öz yeterlik ve alt boyutlarına ilişkin puanlarını betimlemek amacıyla yüzde, frekans ve ortalama gibi merkezi ölçüler kullanılmıştır. Öğrencilerin duygusal zekâ ve psikolojik danışma öz yeterlik düzeylerinin araştırmanın bağımsız değişikliklerine göre farklılıklarını belirlemek amacıyla t- testi ve çoklu karşılaştırmalarda ise varyans analizi (f-testi), farkın kaynağını belirlemek için LSD testi kullanılmıştır. Araştırmada kullanılan iki bağımlı değişken olan duygusal zeka ve psikolojik danışma öz yeterlik düzeyleri arasındaki ilişkiyi belirlemek için Pearson momentler çarpımı korelasyon katsayısı kullanılmıştır.

\section{Bulgular}

\section{Öğrencilerin duygusal zekâ ve psikolojik danışma öz yeterlik düzeyleri}

Araştırmanın birinci alt problemi, PDR ve Psikoloji bölümlerinde öğrenim gören öğrencilerin duygusal zekâ ve psikolojik danışma öz yeterliklerinin ne düzeyde olduğuna ilişkindir. Tablo 2'de söz konusu yeterliklere ilişkin bulgular yer almaktadır.

Tablo 2 incelendiğinde, öğrencilerin duygusal zekâ puan ortalamasının 152,90 olduğu görülmektedir. 97-199 arasında bir puan 
aralığ1 düşünüldüğünde elde edilen puanın ortalama aralığın üzerinde bir puan olduğu söylenebilir. Farklı bir bakış açısıyla, 5'li likert tipi bir ölçek olduğu dikkate alınırsa, öğrenciler duygusal zekâ düzeyleri hakkında "katılıyorum" seçeneğini, yani o özelliklerin kendilerinde olduğunu ifade etmişlerdir. Öğrencilerin en yüksek duygusal zekâ ortalaması sayısal olarak "İyimserlik, ruh halinin düzenlenmesi" seçeneğinde görülse de, puan aralığı dikkate alındığında, üç boyutun da ortalama aralık ile en yüksek aralık arasında olduğu görülmektedir.

Tablo 2. Öğrencilerin duygusal zekâ ve psikolojik danışma öz yeterlik düzeyleri

\begin{tabular}{|c|c|c|c|c|c|c|}
\hline \multirow{2}{*}{$\begin{array}{l}\text { Duygusal Zekâ Ve Psikolojik Danışma } \\
\text { Öz Yeterlik Düzeyleri ve Alt Boyutları } \\
(\mathrm{N}=481)\end{array}$} & \multicolumn{2}{|c|}{ Alınabilecek } & \multicolumn{2}{|c|}{ Alınan } & \multirow[b]{2}{*}{$\begin{array}{l}\text { Ort. } \\
(\bar{X})\end{array}$} & \multirow[b]{2}{*}{$\begin{array}{l}\text { Std. } \\
\text { Sapma }\end{array}$} \\
\hline & $\begin{array}{l}\text { Min. } \\
\text { puan }\end{array}$ & $\begin{array}{l}\text { Max. } \\
\text { puan }\end{array}$ & $\begin{array}{l}\text { Min. } \\
\text { puan }\end{array}$ & $\begin{array}{l}\text { Max. } \\
\text { puan }\end{array}$ & & \\
\hline İyimserlik-Ruh halinin düzenlenmesi & 21 & 105 & 52 & 100 & 78,18 & 9,45 \\
\hline Duyguların Kullanımı & 13 & 65 & 13 & 65 & 46,55 & 10,07 \\
\hline Duyguların Değerlendirilmesi & 7 & 35 & 7 & 35 & 24,03 & 5,49 \\
\hline Toplam Duygusal Zekâ Düzeyi & 41 & 205 & 97 & 199 & 152,90 & 19,72 \\
\hline Yardım Becerileri Öz Yeterlik Düzeyi & 15 & 135 & 32,0 & 135,0 & 98,90 & 18,01 \\
\hline Oturum Yönetmeye İlişkin Öz Yeterlik & $\mathrm{k} 10$ & 90 & 10,0 & 90,0 & 66,48 & 13,74 \\
\hline Düzeyi & 16 & 144 & 24,0 & 144,0 & 92,23 & 22,12 \\
\hline $\begin{array}{l}\text { Zorluklara İlişkin Öz Yeterlik Düzeyi } \\
\text { Toplam Öz Yeterlik Düzeyi }\end{array}$ & 41 & 369 & 74,0 & 369,0 & 257,62 & 48,39 \\
\hline
\end{tabular}

Öğrencilerin psikolojik danışma öz yeterlik düzeyleri açısından Tablo 1'deki veriler dikkate alındığında, öğrencilerin toplam öz yeterlik düzeylerinin de ortalama puan aralığının üzerinde olduğu görülmektedir. Öz yeterlik ölçeğinin alt boyutları açısından da durum aynıdır; en yüksek puan "Oturum yönetmeye ilişkin öz yeterlik düzeyi" alt boyutuna, en düşük puan ise "Zorluklara ilişkin öz yeterlik düzeyi" alt boyutuna ait bulunmuştur. Ancak her üç alt boyuta ait puan ortalaması, ortalama aralığın çok üzerindedir.

\section{Öğrencilerin duygusal zekâ ve psikolojik danışma öz yeterlik düzeylerinin bazı değişkenlere göre farklılıkları}

Öğrencilerin psikolojik danışma öz yeterlikleri ve duygusal zekâ düzeyleri düşünüldüğünde, kadınların karakteristik özelliklerinden dolayı cinsiyet faktörünün belirleyici rol oynayabileceği ve bu yüzden de duygusal zekâ ve psikolojik danışma öz yeterlikleri ile ilgili alan yazında 
yapılmış çalışmaların çoğunda cinsiyet bağımsız bir değişken olarak görülmektedir. Bu çalışmada da bağımsız değişken olarak ele alınan cinsiyete göre söz konusu psikolojik danışma öz yeterlik ve duygusal zekâ düzeylerinin farklılıklarına ilişkin veriler Tablo 3'te yer almaktadır.

Tablo 3. Öğrencilerin cinsiyetlerine göre duygusal zekâ ve psikolojik danışma öz yeterlik düzeyleri

\begin{tabular}{|c|c|c|c|c|c|c|c|}
\hline Bağımlı Değişkenler & Cinsiye & $t \quad N$ & Ort. $(\bar{X})$ & SS & $t$ & sd & $p$ \\
\hline \multirow{2}{*}{ Yardım Becerileri Öz Yeterlik Düzeyi } & $\mathrm{K}$ & 394 & 98,05 & 17,98 & \multirow{2}{*}{$-2,209$} & \multirow{2}{*}{479} & \multirow{2}{*}{, $028^{*}$} \\
\hline & E & 87 & 102,75 & 17,75 & & & \\
\hline \multicolumn{2}{|l|}{ Oturum Yönetmeye İlişkin Öz Yeterlik K } & 394 & 66,10 & 13,95 & \multirow{2}{*}{$-1,302$} & \multirow{2}{*}{479} & \multirow{2}{*}{ 168 } \\
\hline Düzeyi & E & 87 & 68,22 & 12,67 & & & \\
\hline \multirow{2}{*}{ Zorluklara İlişkin Öz Yeterlik Düzeyi } & K & 394 & 91,67 & 21,68 & \multirow{2}{*}{$-1,194$} & \multirow{2}{*}{479} & \multirow{2}{*}{,265 } \\
\hline & E & 87 & 94,79 & 24,00 & & & \\
\hline \multirow{2}{*}{ Toplam Öz Yeterlik Düzeyi } & K & 394 & 255,82 & 48,41 & \multirow{2}{*}{$-1,738$} & \multirow{2}{*}{479} & \multirow{2}{*}{,082 } \\
\hline & E & 87 & 265,76 & 47,73 & & & \\
\hline \multirow{2}{*}{ İyimserlik-Ruh halinin düzenlenmesi } & K & 394 & 78,29 & 9,31 & \multirow{2}{*}{,558 } & \multirow{2}{*}{479} & \multirow{2}{*}{,577 } \\
\hline & $\mathrm{E}$ & 87 & 77,67 & 10,01 & & & \\
\hline \multirow{2}{*}{ Duyguların Kullanımı } & K & 394 & 47,23 & 9,59 & \multirow{2}{*}{3,204} & \multirow{2}{*}{479} & \multirow{2}{*}{, $005^{*}$} \\
\hline & $\mathrm{E}$ & 87 & 43,45 & 11,54 & & & \\
\hline \multirow{2}{*}{ Duyguların Değerlendirilmesi } & K & 394 & 24,59 & 5,22 & \multirow{2}{*}{4,953} & \multirow{2}{*}{479} & \multirow{2}{*}{, $001^{*}$} \\
\hline & E & 87 & 21,45 & 5,96 & & & \\
\hline \multirow{2}{*}{ Toplam Duygusal Zekâ Düzeyi } & K & 394 & 154,28 & 18,98 & \multirow{2}{*}{3,305} & \multirow{2}{*}{479} & \multirow{2}{*}{, $003^{*}$} \\
\hline & E & 87 & 146,64 & 21,80 & & & \\
\hline
\end{tabular}

Elde edilen bir diğer sonuç öğrencilerin psikolojik danışma öz yeterlik düzeylerine ilişkin ortalamalar incelendiğinde; toplam öz yeterlik puanlarının cinsiyete göre farklılaşmadığı, sadece "Yardım becerileri öz yeterlik düzeyi" alt boyutunun istatistiksel olarak anlamlı düzeyde $(\mathrm{t}=$ 2,209; $\mathrm{p}<, 05)$ farklılaştığı ortaya çıkmıştır (tablo 3). Erkek öğrenciler kendilerinin yardım becerileri öz yeterliklerinin ( $\bar{X}=102,75)$ kadın öğrencilerden $(\bar{X}=98,05)$ daha yüksek olduğunu vurgulamaktadır. Öğrencilerin duygusal zekâ düzeylerine ilişkin ortalamalar incelendiğinde ise, gerek toplam zekâ puanlarının, gerekse hem duyguların kullanımı hem de duyguların değerlendirilmesi alt boyutlarına ilişkin puanların cinsiyete göre farklılaştığı, sadece iyimserlik alt boyutu puanlarının anlamlı farklılık göstermediği ortaya çıkmıştır. Toplam duygusal zekâ puan ortalamaları açısından psikolojik danışma öz yeterlik ortalamalarının tersine, kadın öğrencilerin ortalama puanları $(\bar{X}=154,28)$ ile erkek öğrencilerin ortalama puanları $(\bar{X}=146,64)$ 
arasında anlamlı düzeyde $(\mathrm{t}=3,305 ; \mathrm{p}<, 05)$ farklılık görülmektedir. Aynı durum "Duyguların kullanımı" alt boyutunda görülmektedir. Kadın öğrencilerin ortalama puanları $(\bar{X}=47,23)$ erkek öğrencilerin ortalama puanlarına $(\overline{\mathrm{X}}=43,45)$ göre anlamlı düzeyde farklılık $(\mathrm{t}=3,204 ; \mathrm{p}<, 05)$ göstermiştir. "Duygularm değerlendirilmesi" alt boyutunda da kadın öğrencilerin ortalama puanlarının $(\bar{X}=24,11)$ erkek öğrencilerin ortalamalarına $(\bar{X}=21,45)$ anlamlı düzeyde farklılık $(t=4,953 ; p<, 05)$ göstermiştir. Kadın öğrencilerin duyguların değerlendirilmesine ilişkin davranışları erkek öğrencilerden daha fazla gösterdiklerini belirtmişlerdir.

Öğrencilerin öğrenim gördükleri bölümlere göre psikolojik danışma öz yeterlik ve duygusal zekâ davranışlarına ne düzeyde sahip olduklarına ilişkin veriler Tablo 4'te yer almaktadır.

Tablo 4. Öğrencilerin öğrenim gördükleri bölümlere göre psikolojik danışma öz yeterlik ve duygusal zekâ düzeyleri

\begin{tabular}{|c|c|c|c|c|c|c|c|}
\hline Bağımlı Değişkenler & Bölüm & $\mathrm{N}$ & Ort $(\overline{\mathrm{X}})$ & SS & $\mathrm{t}$ & sd & $\mathrm{p}$ \\
\hline \multirow{2}{*}{$\begin{array}{l}\text { Yardım Becerileri Öz Yeterlik } \\
\text { Düzeyi }\end{array}$} & Psikoloji & 288 & 97,42 & 19,05 & \multirow{2}{*}{$-2,288$} & \multirow{2}{*}{479} & \multirow{2}{*}{,023 } \\
\hline & PDR & 193 & 101,11 & 16,12 & & & \\
\hline \multirow{2}{*}{$\begin{array}{l}\text { Oturum Yönetmeye İlişkin } \\
\text { Öz Yeterlik Düzeyi }\end{array}$} & Psikoloji & 288 & 66,212 & 14,47 & \multirow{2}{*}{,- 546} & \multirow{2}{*}{479} & \multirow{2}{*}{,585 } \\
\hline & PDR & 193 & 66,89 & 12,59 & & & \\
\hline \multicolumn{2}{|c|}{ Zorluklara İlişkin Öz Yeterlik Psikoloji } & 288 & 93,06 & 22,58 & \multirow{2}{*}{1,009} & \multirow{2}{*}{479} & \multirow{2}{*}{,318 } \\
\hline Düzeyi & PDR & 193 & 91,00 & 21,43 & & & \\
\hline \multirow{2}{*}{ Toplam Öz Yeterlik Düzeyi } & Psikoloji & 288 & 256,69 & 50,09 & \multirow{2}{*}{,- 524} & \multirow{2}{*}{479} & \multirow{2}{*}{ 601 } \\
\hline & PDR & 193 & 259,01 & 45,82 & & & \\
\hline \multirow{2}{*}{$\begin{array}{l}\text { İyimserlik - Ruh halinin } \\
\text { düzenlenmesi }\end{array}$} & Psikoloji & 288 & 77,25 & 10,12 & \multirow{2}{*}{$-2,753$} & \multirow{2}{*}{479} & \multirow{2}{*}{, $006^{*}$} \\
\hline & PDR & 193 & 79,56 & 8,17 & & & \\
\hline \multirow{2}{*}{ Duyguların Kullanımı } & Psikoloji & 288 & 44,24 & 10,71 & \multirow{2}{*}{$-6,786$} & \multirow{2}{*}{479} & \multirow{2}{*}{, $000^{*}$} \\
\hline & PDR & 193 & 50,00 & 7,87 & & & \\
\hline Duyguların & Psikoloji & 288 & 23,44 & 6,06 & \multirow{2}{*}{$-3,075$} & \multirow{2}{*}{479} & \multirow{2}{*}{, $002^{*}$} \\
\hline Değerlendirilmesi & PDR & 193 & 24,90 & 4,37 & & & \\
\hline Toplam Duygusal Zekâ & Psikoloji & 288 & 149,02 & 20,62 & \multirow{2}{*}{$-5,649$} & \multirow{2}{*}{479} & \multirow{2}{*}{, $000^{*}$} \\
\hline Düzeyi & PDR & 193 & 158,69 & 16,74 & & & \\
\hline
\end{tabular}

Tablo 4'te görüldüğü gibi, öğrencilerin öğrenim gördükleri bölümlere göre öz yeterlik düzeyleri farklılaşmazken, duygusal zekâ düzeyleri bölümlere göre farklılık göstermiştir. Öğrencilerin cinsiyetlerine ilişkin verilerde (Tablo 3) görüldüğü gibi, bölümlerine ilişkin verilerde de 
paralellik bulunmaktadır. "Yardım becerileri öz yeterlik düzeyleri" alt boyutu dişında gerek alt boyutlar, gerekse toplam psikolojik danışma öz yeterlik davranışlarına ait puanlar öğrencilerin bölümlerine göre farklılık göstermemektedir. Yardım alt boyutunda PDR bölümünde okuyan öğrenciler söz konusu davranışlara daha fazla ( $\bar{X}=101,11)$ sahip olduklarını ifade etmişlerdir. Psikoloji bölümü öğrencilerine ilişkin ortalama $(\bar{X}=97,42)$ ile PDR öğrencilerine ait ortalamaların anlamlı düzeyde farklılık $(t=-2,288 ; p<, 05)$ gösterdiği ortaya çıkmıştır. Duygusal zekâ ölçeğinden elde edilen puanlar bölümlere göre değerlendirildiğinde; toplam duygusal zekâ puanları açısından PDR öğrencilerinin $(\bar{X}=158,69)$ ortalama puanlarının Psikoloji bölümü öğrencilerinden daha yüksek $(\bar{X}=149,02)$ olduğu görülmektedir. Her iki ortalama karşılaştırıldığında, puanlar arasında anlamlı düzeyde farklılık $(t=-5,649 ; p<, 05)$ olduğu gözlenmektedir. Söz konusu durum her üç alt boyut açısından da benzerlik göstermektedir; iyimserlik alt boyutunda $(\mathrm{t}=-2,753 ; \mathrm{p}<, 05)$, duyguların kullanımı alt boyutunda $(\mathrm{t}=-6,786 ; \mathrm{p}<, 05)$ ve duyguların değerlendirilmesi alt boyutunda $(t=-3,075 ; \mathrm{p}<, 05)$ PDR öğrencilerinin söz konusu davranışlara Psikoloji bölümü öğrencilerinden daha fazla sahip oldukları ortaya çıkmıştır.

Tablo 5. Öğrencilerin psikolojik yardım alma durumlarına göre psikolojik danışma öz yeterlik ve duygusal zekâ düzeyleri

\begin{tabular}{|c|c|c|c|c|c|c|c|}
\hline Bağımlı Değişkenler & $\begin{array}{l}\text { Psik. } \\
\text { Yardım }\end{array}$ & $\mathrm{N}$ & $\operatorname{Ort}(\overline{\mathrm{X}})$ & SS & $\mathrm{t}$ & sd & $\mathrm{p}$ \\
\hline \multicolumn{2}{|c|}{ Yardım Becerileri Öz YeterlikEvet } & 98 & 98,38 & 21,18 & \multirow{2}{*}{,- 285} & \multirow{2}{*}{479} & \multirow{2}{*}{, 776} \\
\hline Düzeyi & Hayır & 383 & 99,04 & 17,13 & & & \\
\hline \multicolumn{2}{|c|}{ Oturum Yönetmeye İlişkinEvet } & 98 & 65,27 & 15,63 & \multirow{2}{*}{,- 892} & \multirow{2}{*}{479} & \multirow{2}{*}{,374 } \\
\hline Öz Yeterlik Düzeyi & Hayır & 383 & 66,80 & 13,22 & & & \\
\hline \multicolumn{2}{|c|}{ Zorluklara İlişkin Öz YeterlikEvet } & 98 & 88,06 & 25,51 & \multirow{2}{*}{$-1,875$} & \multirow{2}{*}{479} & \multirow{2}{*}{,063 } \\
\hline Düzeyi & Hayır & 383 & 93,30 & 21,08 & & & \\
\hline \multirow{2}{*}{ Toplam Öz Yeterlik Düzeyi } & Evet & 98 & 251,70 & 54,89 & \multirow{2}{*}{$-1,231$} & \multirow{2}{*}{479} & \multirow{2}{*}{220} \\
\hline & Hayır & 383 & 259,13 & 46,54 & & & \\
\hline \multirow{2}{*}{$\begin{array}{l}\text { İyimserlik-Ruh } \\
\text { düzenlenmesi }\end{array}$} & inEvet & 98 & 79,13 & 10,25 & \multirow{2}{*}{1,053} & \multirow{2}{*}{479} & \multirow{2}{*}{,294 } \\
\hline & Hayır & 383 & 77,94 & 9,23 & & & \\
\hline \multirow{2}{*}{ Duyguların Kullanımı } & Evet & 98 & 43,48 & 12,10 & \multirow{2}{*}{$-2,937$} & \multirow{2}{*}{479} & \multirow{2}{*}{, $004^{*}$} \\
\hline & Hayır & 383 & 47,33 & 9,33 & & & \\
\hline Duyguların & Evet & 98 & 23,46 & 6,56 & \multirow{2}{*}{,- 995} & \multirow{2}{*}{479} & \multirow{2}{*}{, 322} \\
\hline Değerlendirilmesi & Hayır & 383 & 24,17 & 5,18 & & & \\
\hline Duygusal & kâEvet & 98 & 150,26 & 23,11 & \multirow{2}{*}{$-1,318$} & \multirow{2}{*}{479} & \multirow{2}{*}{ 190 } \\
\hline Düzeyi & Hayır & 383 & 153,58 & 18,72 & & & \\
\hline
\end{tabular}


Öğrencilerin daha önce psikolojik yardım alıp almadıklarına göre psikolojik danısma öz yeterlik düzeyleri ve duygusal zekâ düzeylerinin farklılıklarına ilişkin veriler Tablo 5'te yer almaktadır.

Yukarıdaki tablo incelendiğinde; öğrencilerin psikolojik yardım alıp almama durumlarına göre, duygusal zekâ ve psikolojik danışma öz yeterlik düzeylerinin anlamlı düzeyde değişmediği görülmektedir. Her iki değişkene ilişkin ortalamalar karşılaştırıldığında, psikolojik yardım almamış olan öğrencilerin gerek duygusal zekâ ve gerekse psikolojik danışma öz yeterlik düzeylerine ilişkin puanlarının yardım alanlara oranla daha yüksek olduğu ortaya çıkmıştır. Duygusal zekâ ölçeğinin sadece "duygularm kullanımı" alt boyutunda psikolojik yardım almayan öğrencilerin puan ortalamaları $(\overline{\mathrm{X}}=47,33)$ alanlara $(\overline{\mathrm{X}}=43,48)$ göre anlamlı

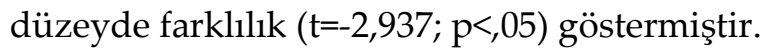

Öğrencilerin psikolojik danışma öz yeterlik ve duygusal zekâ düzeylerinin öğrencilerin bölümlerini isteyerek seçip seçmemelerine göre farklılıklarına ilişkin veriler Tablo 6 ' da yer verilmiştir.

Öğrencilerin öğrenim gördükleri bölümü severek tercih etme durumlarına göre psikolojik danışma öz yeterlik ve duygusal zekâ düzeylerine ilişkin Tablo 6' daki veriler incelendiğinde, genellikle severek tercih edenlerin her iki ölçek ve alt boyutlarından alınan ortalama puanlar, kısmen ve hayır seçeneğini işaretleyenlere oranla daha yüksek bulunmuştur. Toplam psikolojik danı̧̧ma öz yeterlik düzeylerine ilişkin ortalamalar dikkate alındığında; öğrenim gördükleri bölümü isteyerek tercih eden öğrencilerin ortalamaları $(\bar{X}=261,10)$ ile bölümü sevmeyen öğrencilerin ortalamaları ( $\overline{\mathrm{X}}=234,41)$ arasında anlamlı düzeyde farklılık $(\mathrm{F}=4,555 ; \mathrm{p}<, 05)$ ortaya çıtığı görülmektedir. Psikolojik danışma öz yeterlik ölçeğinin "Yardım becerileri öz yeterlik düzeyi" alt boyutuna ilişkin veriler incelendiğinde, evet diyen grubun ortalamaları $(\bar{X}=100,20)$ ile kısmen diyen grubun ortalamaları $(\overline{\mathrm{X}}=95,52)$ arasında anlamlı düzeyde farklılık $(F=3,524 ; p<, 05)$ gözlenmektedir. Oturumu yönetmeye ilişkin öz yeterlik düzeylerine ilişkin veriler incelendiğinde; her üç grup ortalamaları arasında anlamlı düzeyde farklılı̆ın $(\mathrm{F}=10,957 ; \mathrm{p}<, 05)$ olduğu göze çarpmaktadır. Zorluklara ilişkin öz yeterlik boyutunda gruplar arasında istatistiksel olarak anlamlı bir fark bulunmamıştır. 
Psikoloji Eğitimi alan öğrencilerin Duygusal Zekâ ve Psikolojik Danışma Öz-Yeterliklerinin İncelenmesi

Tablo 6. Öğrencilerin psikolojik danışma öz yeterlik ve duygusal zekâ düzeylerinin öğrencilerin bölümlerini isteyerek seçip seçmemelerine göre farklılıkları

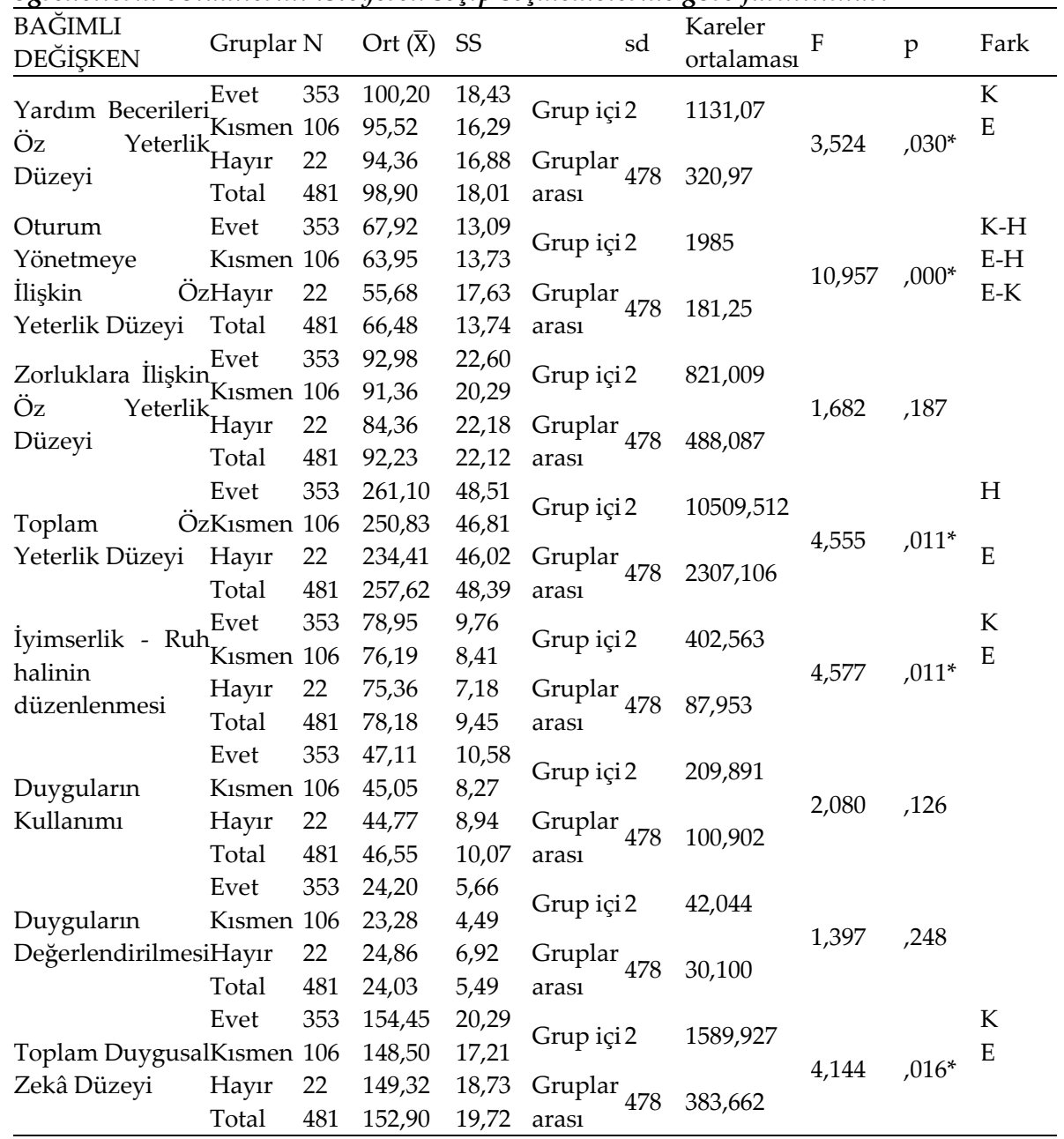

Duygusal zekâ ölçeğinden toplam alınan puan ortalamaları dikkate alındığında, evet grubunun ortalaması ( $\overline{\mathrm{X}}=154,45)$ ile kısmen diyen grubun ortalamaları $(\overline{\mathrm{X}}=148,50)$ arasinda anlamlı düzeyde $(\mathrm{F}=4,144 ; \mathrm{p}<, 05)$ farklılığın ortaya çıktığı görülmektedir. Duygusal zeka ölçeğinin İyimserlik, ruh halinin düzenlenmesi alt boyutunda gruplar arasında farklılık $(\mathrm{F}=4,577 ; \mathrm{p}<, 05)$ ortaya çıkmıştır. Yapılan LSD testi sonucunda, farklılı̆̆ın evet diyen grubun ortalaması $(\overline{\mathrm{X}}=78,95)$ ile kısmen diyen grubun 
ortalaması $(\overline{\mathrm{X}}=75,36)$ arasında olduğu görülmektedir. Duyguların kullanımı ve duyguların değerlendirilmesi alt boyutlarında anlamlı bir farklılık bulunmamıştır.

Öğrencilerin öğrenim gördükleri bölümü sevip sevmemelerine göre psikolojik danışma öz yeterlikleri ve duygusal zekâ düzeylerine ilişkin anova testi sonuçlarına Tablo 7 'de verilmiştir.

Tablo 7. Öğrencilerin öğrenim gördükleri bölümü sevip sevmemelerine göre psikolojik danışma öz yeterlikleri ve duygusal zekâ düzeyleri

\begin{tabular}{|c|c|c|c|c|c|c|c|c|c|c|}
\hline & & $\mathrm{N}$ & Ort & SS & & $\mathrm{sd}$ & $\begin{array}{c}\text { Kareler } \\
\text { ortalamas1 }\end{array}$ & $\mathrm{F}$ & $\mathrm{p}$ & Fark \\
\hline \multirow{4}{*}{$\begin{array}{l}\text { Yardım Becerileri } \\
\text { Öz Yeterlik Düzeyi }\end{array}$} & Evet & 333 & 100,71 & 18,33 & & & & \multirow{4}{*}{10,864} & \multirow{4}{*}{, $000^{*}$} & $\mathrm{H}$ \\
\hline & Kismen & 117 & 97,26 & 16,13 & Gru & 2 & 3384,50 & & & $\mathrm{H}$ \\
\hline & Hayır & 31 & 85,74 & 15,44 & Gruplar & 478 & 311538 & & & E-K \\
\hline & Total & 481 & 98,90 & 18,01 & arası & $4 / 8$ & 311,538 & & & \\
\hline \multirow{4}{*}{$\begin{array}{l}\text { Oturum Yönetmey } \\
\text { İlişkin Öz Yeterlik } \\
\text { Düzeyi }\end{array}$} & Evet & 333 & 68,20 & 13,36 & Grun ici & 2 & 3275 & \multirow{4}{*}{18,626} & \multirow{4}{*}{, $000^{*}$} & K-H \\
\hline & Kismen & 117 & 65,09 & 12,87 & 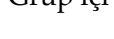 & & & & & E-H \\
\hline & Hayır & 31 & 53,36 & 13,64 & Gruplar & 478 & 175856 & & & E-K \\
\hline & Total & 481 & 66,48 & 13,74 & arası & & (17,0,0 & & & \\
\hline \multirow{4}{*}{$\begin{array}{l}\text { Zorluklara İlişkin } \\
\text { Öz Yeterlik Düzeyi }\end{array}$} & Evet & 333 & 94,39 & 22,30 & $G$ & 2 & 5744,229 & \multirow{4}{*}{12,287} & \multirow{4}{*}{, $000^{*}$} & $\mathrm{H}$ \\
\hline & Kismen & 117 & 90,78 & 19,32 & & & & & & $\mathrm{H}$ \\
\hline & Hayır & 31 & 74,55 & 22,46 & Gruplar & 478 & 467,487 & & & E-K \\
\hline & Total & 481 & 92,23 & 22,12 & aras1 & & & & & \\
\hline \multirow{4}{*}{$\begin{array}{l}\text { Toplam Öz Yeterlil } \\
\text { Düzeyi }\end{array}$} & Evet & 333 & 263,29 & 48,93 & & 2 & 36 & \multirow{4}{*}{16,610} & \multirow{4}{*}{, $000^{*}$} & $\mathrm{~K}-\mathrm{H}$ \\
\hline & Kismen & 117 & 253,12 & 43,02 & & & 30 & & & E-H \\
\hline & Hayır & 31 & 213,65 & 37,14 & Gruplar & 478 & 2198302 & & & E-K \\
\hline & Total & 481 & 257,62 & 4839 & (a) & $4 / 0$ & 2190,502 & & & \\
\hline \multirow{4}{*}{$\begin{array}{l}\text { İyimserlik - Ruh } \\
\text { halinin } \\
\text { düzenlenmesi }\end{array}$} & Evet & 333 & 79,10 & 10,08 & ici & 2 & 469585 & \multirow{4}{*}{5,356} & \multirow{4}{*}{, $005^{*}$} & $\mathrm{~K}-\mathrm{H}$ \\
\hline & Kismen & 117 & 76,27 & 6,89 & & & & & & E-H \\
\hline & Hayır & 31 & 75,45 & 9,40 & Gruplar & 478 & 87,672 & & & E \\
\hline & Total & 481 & 78,18 & 9,45 & arog & & & & & \\
\hline \multirow{4}{*}{$\begin{array}{l}\text { Duyguların } \\
\text { Kullanımı }\end{array}$} & Evet & 333 & 47,03 & 10,65 & Grup içi & 2 & 137,877 & \multirow{4}{*}{1,362} & \multirow{4}{*}{ 257 } & \\
\hline & Kismen & 117 & 45,66 & 8,45 & & & & & & \\
\hline & Hayır & 31 & 44,71 & 9,05 & Gruplar & 478 & 101,204 & & & \\
\hline & Total & 481 & 46,55 & 10,07 & 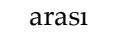 & $4 / 0$ & 101,204 & & & \\
\hline \multirow{4}{*}{$\begin{array}{l}\text { Duyguların } \\
\text { Değerlendirilmesi }\end{array}$} & Evet & 333 & 24,01 & 5,52 & Grup içi & 2 & 47,017 & \multirow{4}{*}{1,563} & \multirow{4}{*}{ 211 } & \\
\hline & Kismen & 117 & 23,66 & 4,97 & Giup tç1 & 2 & 47,017 & & & \\
\hline & Hayır & 31 & 25,61 & 6,81 & Gruplar & 478 & 30 & & & \\
\hline & Total & 481 & 24,02 & 5,49 & 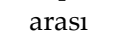 & $4 / 8$ & $30,0 / 9$ & & & \\
\hline \multirow{4}{*}{$\begin{array}{l}\text { Toplam Duygusal } \\
\text { Zeka Düzeyi }\end{array}$} & Evet & 333 & 154,31 & 20,53 & ci & 2 & 1076.679 & \multirow{4}{*}{2,791} & \multirow{4}{*}{,062 } & K \\
\hline & Kismen & 117 & 149,68 & 15,77 & Giup ţ̧ı & & & & & E \\
\hline & Hayır & 31 & 149,94 & 22,79 & Gruplar & 478 & 385,810 & & & \\
\hline & Total & 481 & 152,90 & 19,72 & arası & & 300,010 & & & \\
\hline
\end{tabular}


Tablo 7 incelendiğinde, öğrencilerin öğrenim gördükleri bölümleri sevip sevmemelerine göre özellikle psikolojik danışma öz yeterlik puanları açısından gruplar arasında farklılığın çıtığı görülmektedir. Yapılan Anova testi sonucunda, Psikolojik danışma öz yeterlik ölçeğinin tamamından alınan puanlar açısından gruplar arasında anlamlı düzeyde farklılığın $(\mathrm{F}=16,610 ; \mathrm{p}<, 05)$ ortaya çıtığı, bu farkın da tüm gruplar arasında olduğu gözlenmektedir. Öğrenim gördükleri bölümden memnun olan öğrencilerin ortalama puanlarının $(\bar{X}=263,29)$, bölümlerinden kısmen ( $\overline{\mathrm{X}}=253,12)$ memnun olanlardan ve bölümlerinden memnun olmayan öğrencilerin ortalama puanlarından $(\bar{X}=213,65)$ daha yüksek bulunmuştur. Yardım becerileri öz yeterlik puanları açısından, bölümlerinden memnun olmayan öğrencilerin ortalama puanları $(\bar{X}=85,74)$ ile bölümlerinden memnun olan $(\bar{X}=100,71)$ ve kısmen memnun olan öğrencilerin ortalama puanları $(\overline{\mathrm{X}}=92,26)$ arasında anlamlı düzeyde farklılık $(\mathrm{F}=10,864 ; \mathrm{p}<, 05)$ ortaya çıkmıştır. Benzer bir durum "Oturumu Yönetmeye İlişkin Öz Yeterlik" alt boyutunda da görülmektedir. Oturumu yönetmeye ilişkin öz yeterlik davranışlarını bölümünden memnun olan öğrencilerin daha $(\overline{\mathrm{X}}=68,20)$ fazla gösterdiği, bölümlerinden kısmen memnun olanlar $(\bar{X}=65,09)$ ve memnun olmayan öğrencilerin $(\bar{X}=53,36)$ daha az gösterdiği ortaya çıkmıştır. Söz konusu farklılıklar gruplar arasında anlamlı düzeyde farklılık $(\mathrm{F}=18,626 ; \mathrm{p}<, 05)$ oluşturmuştur.

Farklılığın kaynağını bulmak amacıyla yapılan LSD testinde, her üç grubun da bu farklılığa neden olduğu görülmektedir. Zorluklara ilişkin öz yeterlik düzeyi açısından bakıldığında, aynı şekilde bölümlerinden memnun musunuz sorusuna evet diyen öğrencilerin ortalamaları diğer iki gruptan daha yüksek bulunmuştur. Bir başka ifadeyle, zorluklara ilişkin öz yeterlik düzeylerine ilişkin davranışlara en fazla ( $\bar{X}=9439)$ sahip olduğunu, bölümlerinden kısmen memnun olanların söz konusu davranışlara daha az sahip oldukları $(\bar{X}=90,78)$ ve son olarak bölümlerinden memnun olmayan öğrencilerin ortalama puanlarının en düşük $(\bar{X}=74,55)$ olduğu ortaya çıkmıştır. Yapılan LSD testi sonucunda, hayır diyen grubun ortalama puanlarının diğer iki grupta yer alan öğrencilerin puanları arasında anlamlı düzeyde farklılığın olduğu görülmüş̧ür. 
Öğrencilerin duygusal zeka düzeyleri ölçeğinin tamamından alınan puanlar dikkate alındığında; bölümlerinden memnun olan ve kısmen memnun olan öğrencilerin puanları arasında kısmen bir fark ortaya çıkmış, ancak sonuç itibariyle bu fark istatistiksel olarak anlamlı bulunmamıştır. Öğrencilerin "İyimserlik - ruh halinin düzenlenmesi" alt boyutundan aldıkları puanlar incelendiğinde, gruplar arasında istatistiksel olarak bir farkın $(\mathrm{F}=5,356 ; \mathrm{p}<, 05)$ ortaya çıktığı, bu farkın da her üç grubun puanlarından kaynaklandığı görülmektedir. Duyguların kullanımı ve değerlendirilmesi alt boyutları açısından gruplar arasında bir farklılık bulunmamıştır.

\section{Öğrencilerin duygusal zekâ ve psikolojik danışma öz yeterlik düzeyleri arasındaki ilişki}

Bir bireyin psikolojik danışma öz yeterliliklerinin beklenen düzeyde olabilmesi onun kendi duygularını tanıyabilmesine, çevresini doğru algılayabilmesine, başkalarının duygularını tanımlama ve duygudaşlık (empati) yapabilme gücüne bağlıdır. Bu sayılan özelliklerin çoğu bireyin duygusal zekâsıyla ilgili bir durumdur. Tablo 8'de öğrencilerin psikolojik danışma öz yeterlikleri ve duygusal zeka düzeylerinin arasındaki ilişkiye ilişkin korelasyon sonuçları yer almaktadır.

Tablo 8. Psikolojik danışma öz yeterlik ve duygusal zekâ düzeyi arasındaki ilişki

\begin{tabular}{|c|c|c|c|c|c|}
\hline & & $\begin{array}{l}\text { İyimserlik- } \\
\text { Ruh halinin } \\
\text { düzenlenmesi }\end{array}$ & $\begin{array}{c}\text { Duyguların } \\
\text { Kullanımı } \\
\end{array}$ & $\begin{array}{c}\text { Duyguların } \\
\text { Değerlendirilmesi }\end{array}$ & $\begin{array}{c}\text { Toplam } \\
\text { Duygusal } \\
\text { Zekâ Düzeyi } \\
\end{array}$ \\
\hline Yardım Becerileri & $\mathrm{r}$ &, $581^{* *}$ & $251^{* *}$ &,- 031 & $414^{* *}$ \\
\hline \multirow[t]{2}{*}{ Öz Yeterlik Düzeyi } & Sig. (2-tailed) &, 000 & ,000 & ,494 & ,000 \\
\hline & $\mathrm{N}$ & 481 & 481 & 481 & 481 \\
\hline \multicolumn{2}{|l|}{ Oturum Yönetmeyer } & $637^{* *+}$ & $277^{*+*}$ & , 026 &, $471^{* *}$ \\
\hline İlişkin Öz Yeterlik & Sig. (2-tailed) &, 000 & ,000 &, 573 & ,000 \\
\hline Düzeyi & $\mathrm{N}$ & 481 & 481 & 481 & 481 \\
\hline Zorluklara İlişkin & r &, $503^{* *}$ & $143^{* * *}$ &,$- 110^{*}$ & $296^{* *}$ \\
\hline \multirow[t]{2}{*}{ Öz Yeterlik Düzeyi } & Sig. (2-tailed) &, 000 & ,002 & ,016 &, 000 \\
\hline & $\mathrm{N}$ & 481 & 481 & 481 & 481 \\
\hline Toplam Psik. Dan. & $\mathrm{r}$ & $627^{* * *}$ & $238^{* * *}$ &,- 055 & $423^{* *}$ \\
\hline \multirow[t]{2}{*}{ Öz Yeterlik Düzeyi } & Sig. (2-tailed) & ,000 & ,000 & ,232 & ,000 \\
\hline & $\mathrm{N}$ & 481 & 481 & 481 & 481 \\
\hline
\end{tabular}

${ }^{* *}$ Correlation is significant at the 0.01 level (2-tailed).

${ }^{*}$ Correlation is significant at the 0.05 level (2-tailed). 
Yukarıdaki tablo (Tablo 8) incelendiğinde, psikolojik danışma öz yeterlikleri toplam puanları ile duygusal zekâ düzeyi toplam puanları arasında doğrusal bir ilişkinin $(\mathrm{r}=, 423)$ olduğu ve bu ilişkinin 0,01 düzeyinde anlamlı olduğu görülmektedir. Bir başka ifadeyle, öğrencilerin psikolojik danışma öz yeterlik düzeyleri yükseldikçe, duygusal zekâ düzeylerinin de yükseldiği veya tam tersi duygusal zekâ düzeyi yükseldikçe, psikolojik danışma öz yeterlik düzeylerinin yükseldiği ifade edilebilir. Zekânın zamanla ya da eğitimle yükselmeyeceği varsayılırsa, duygusal zekâ arttıkça psikolojik danışma öz yeterliklerinin artması sonucu çıkarılabilir. Duygusal zekâ ve psikolojik danışma öz yeterlikleri arasında en yüksek ilişki $(r=, 637)$, oturumu yönetmeye ilişkin öz yeterlik düzeyi ve duygusal zekâ alt boyutu olan iyimserlik - ruh halinin düzenlenmesi düzeyi arasında, en düşük ilişki de $(r=-, 031)$, yardım becerileri öz yeterlik düzeyi ile duygusal zekâ alt boyutu olan duyguların değerlendirilmesi arasında ortaya çıkmıştır. Duyguların değerlendirilmesi alt boyutu ile sadece zorluklara ilişkin öz yeterlik düzeyi arasında ters yönde bir ilişkinin ( $\mathrm{r}=$ ,110) dışında diğer alt boyutlar arasında bir ilişki ortaya çıkmamıştır.

\section{Öğrencilerin duygusal zekâ düzeyleri psikolojik danışma öz yeterlik düzeylerini etkileme seviyesi}

Araştırmanın bir diğer amacı olarak öğrencilerin duygusal zeka düzeylerinin öz yeterlilik düzeylerini etkileme seviyesini incelemektir. Bunun için katılımcıların verdikleri cevaplardan 'duygusal zeka düzeyleri' ile ilgili veriler bağımsız ve 'psikolojik danışma öz yeterlilik düzeyleri' ise bağımlı değişken olarak ele alınmıştır. Öğrencilerin psikolojik danışma öz yeterlik düzeylerinin duygusal zekadan ne düzeyde etkilendiğine ilişkin veriler Tablo 9' da yer almaktadır.

Tablo 9. Öğrencilerin duygusal zeka düzeyleri ve psikolojik danışma öz yeterlilik düzeyleri arasındaki ilişkiye ilişkin regresyon modeli

\begin{tabular}{ccccc}
\hline Model & $\mathrm{R}$ & R-Kare & $\begin{array}{c}\text { Hatalardan arınık } \\
\text { R-Kare }\end{array}$ & Standart kestirim hatasi \\
\hline 1 & 0,423 & 0,179 & 0,177 & 43,89 \\
\hline
\end{tabular}

a. Bağımlı değişken: Psikolojik danışma öz yeterlik düzeyi 
b. Bağımsız değişken: Duygusal zeka düzeyi

Yukarıda (Tablo 9) verilen her iki değişkenin birlikte işe koşulduğu regresyon modeline göre elde edilen Pearson korelasyon katsayısı 0,423 olarak hesaplanmıştır (Tablo 8 ve 9). Bu sonuç iki değişken arasında orta düzeyde ve pozitif yönde bir ilişki olduğunu göstermektedir. Ayrıca öğrencilerin Psikolojik danışma öz yeterlik düzeylerinin yaklaşık \% 18'lik (R-Kare=0,179) bir bölümünü de duygusal zeka düzeyleri ile açıklamak mümkündür. Sonuç olarak katılımcılardan toplanan verilere göre, öğrencilerin duygusal zeka düzeylerinin psikolojik danışma öz yeterlilik düzeylerini pozitif olarak etkilediği ifade edilebilir.

Öğrencilerin duygusal zeka düzeyi ile psikolojik danışma öz yeterlilik düzeyleri arasındaki ilişkinin anlamlılı̆̆ını test etmek amacıyla yapılan Anova testi sonuçları Tablo 10'da yer almaktadır.

Tablo 10. Öğrencilerin duygusal zeka düzeyleri ve psikolojik danışma öz yeterlilik düzeyleri arasındaki ilişkinin anlamlılı̆̆ına ilişkin Anova Testi

\begin{tabular}{ccccccc}
\hline & \multirow{2}{*}{ Model } & Kareler Toplamı & sd & $\begin{array}{c}\text { Karelerin } \\
\text { Ortalaması }\end{array}$ & F & p \\
\hline \multirow{2}{*}{1} & Gruplar Arası & 201245,385 & 1 & 201245,385 & 104,49 &, $000^{\mathrm{b}}$ \\
& Grup İçi & 922570,229 & 479 & 1926,034 & & \\
& Toplam & 1123815,613 & 480 & & & \\
\hline
\end{tabular}

a. Bă̆ımlı değişken: Psikolojik danışma öz yeterlik düzeyi

b. Bağımsız değişken: Duygusal zeka düzeyi

Tablo 10 incelendiğinde, öğrencilerin duygusal zeka düzeyleri ile psikolojik danışma öz yeterlikleri arasında tespit edilen ilişki düzeyinin $(R=0,423)$ istatistiksel olarak anlamlı $(p=, 000)$ olduğu görülmektedir.

Tablo 11'de elde edilen bulguların model parametreleri gösterilmiştir.

Tablo 11. Regresyon denklemindeki katsayı ve sabitleri içeren model parametreleri

\begin{tabular}{|c|c|c|c|c|c|c|}
\hline \multirow[b]{2}{*}{ Model } & & \multicolumn{2}{|c|}{$\begin{array}{c}\text { Standart olmayan } \\
\text { Katsayilar }\end{array}$} & $\begin{array}{l}\text { Standart } \\
\text { Katsayilar }\end{array}$ & \multirow[b]{2}{*}{$t$} & \multirow[b]{2}{*}{ Sig } \\
\hline & & B & Std. Sapma & Beta & & \\
\hline 1 & (Sabit) & 98,82 & 15,66 & & 6,31 & , 000 \\
\hline & $\begin{array}{l}\text { Toplam Duygusal Zeka } \\
\text { Düzeyi }\end{array}$ & 1,04 & 102 & 423 & 10,22 & , 000 \\
\hline
\end{tabular}

a. Bağımlı Değişken: Toplam Psikolojik Danışma Öz Yeterlik Düzeyi

Buna göre, bağımlı değişken psikolojik danışma öz yeterlilik düzeyinin duygusal zeka düzeyi artışından daha fazla artış gösterdiği 
söylenebilir. Buna ilaveten, iki değişken arasında hesaplanan standart veya standart olmayan katsayılar istatistiksel olarak anlamlı bir farklılık ortaya koymuşlardır $(\mathrm{p}<0,05)$.

Sonuç olarak, öğrencilerin duygusal zeka düzeylerinin psikolojik danışma öz yeterlik düzeylerinin ne kadarını açıkladığını belirlemek için yapılan basit doğrusal regresyon analizi sonucunda, öğrencilerin duygusal zekaları ile psikolojik danışma öz-yeterlikleri arasında anlamlı bir ilişki gözlenmiş $\left(R=0,423, R^{2}=0,179\right)$, öğrencilerin algıladıkları duygusal zeka düzeylerinin psikolojik danışma öz-yeterlik düzeylerinin anlamlı bir yordayıcısı olduğu görülmüştür $\left(\mathrm{F}_{(1-479)}=104,49, \mathrm{p}<, 05\right)$. Öğrencilerin duygusal zeka düzeyleri psikolojik danışma öz-yeterlik düzeylerinin \% 17,9'unu açılamaktadır. Regresyon denklemine esas yordayıcı değişkenin katsayısının $(B=1,04)$ anlamlılık testi de, öğrencilerin duygusal zekalarının anlamlı bir yordayıcı olduğunu göstermektedir $(\mathrm{p}<, 01)$.

Elde edilen bilgilere göre zeka seviyeleri ile öz yeterlilik arasındaki ilişki aşağıdaki eşitlik ile ifade edilebilir:

Tahmin edilen öz yeterlilik düzeyi $=98,82-(1,04 *$ duygusal zeka düzeyi).

\section{Tartışma ve Öneriler}

Öğrencilerin duygusal zeka ve psikolojik danışma öz yeterlik düzeyleri PDR ve Psikoloji bölümlerinde okuyan öğrencilerin psikolojik danışma öz yeterlik ve duygusal zekâ düzeylerini ve her iki değişken arasındaki ilişkiyi inceleyen bu çalışmada; öğrencilerin, algıladıkları duygusal zekâ düzeylerinin ortalamanın üstünde olduğunu belirtmişlerdir. Başka bir deyişle, öğrenciler duygusal zekâ ile ilgili davranışların büyük bir çoğunluğuna sahip olduklarını ifade etmişlerdir. Ölçekten ve alt boyutlarından alınan puanlar orta ve en yüksek arasında elde edilmiştir. Öğrencilerin psikolojik danışma öz yeterlik düzeyleri açısından da durum aynıdır. Öğrenciler gerek ölçekten gerekse alt boyutlarından ortalamanın üzerinde puan almışlardır.

Dutoğlu ve Tuncel (2008) tarafından yapılan çalışmada, aday öğretmenlerin eleştirel düşünme ve duygusal zeka düzeylerinin yüksek olmadığı ortaya çıkmıştır. Bu durum yine benzer sonuçların elde edildiği 
bir çalışmada (Yurdakavuştu, 2012) erkeklerin beynin sol yarım küresini, kızların ise sağ yarım küresini kullandıklarından kaynaklandığı ileri sürülmüştür. Aynı araştırma, kızlar sağ yarım küreye bağlı olarak duygusal süreçler de sezgilerine güvenirken, erkekler sol yarımküreye bağlı olarak analitik düşünceye güvendiklerini göstermektedir. Hemşirelik öğrencilerinin duygusal zeka düzeyleri ve problem çözme becerilerini belirlemek ve öğrencilerin duygusal zeka düzeylerinin problem çözme becerilerine etkisini araştırmak amacıyla yapılan bir araştırmada (Karabulutlu, Yılmaz, \& Yurttaş, 2011), öğrencilerin toplam duygusal zeka düzeyi puanlarının ortalamanın biraz üzerinde olduğu belirlenmiştir. Aslan ve Güzel (2018), tarafından yapılan ve duygusal zeka ile problem odaklı stresle başa çıkma, iyileşme ve duygusal tükenme ilişkilerinin incelendiği çalışmada, duygusal zekanın problem odaklı stresle başa çıkmayı pozitif yönde etkilediği, problem odaklı stresle başa çıkma davranışın da duygusal tükenmeyi azaltırken iyileşmeyi artırdığı ortaya çıkmıştır. Yapılan araştırmalardan da anlaşılacağı üzere duygusal zekanın eleştirel düşünme, problem çözme, stresle başa çıkma, liderlik ve sosyal beceri düzeyleri gibi bir çok değişkenle ilişkilidir ve bireyin söz konusu becerilerini olumlu yönde etkilemektedir. O halde öğrencilere özellikle ana sınıfından başlayarak birlikte çalışma, sorun çözme, yaparak öğrenme gibi etkinlikleri giderek artan bir şekilde göstermekte yarar vardır.

Yine bu çalışma sonuçlarına paralel olarak, Aksoy ve Diken (2009) tarafından yapılan ve rehber öğretmenlerin öz yeterlik algılarının incelendiği bir çalışmada, rehber öğretmenlerin özel eğitimde psikolojik danışma ve rehberliğe ilişkin öz yeterlik algılarının orta düzeyde olduğu belirlenmiştir.

Öğrencilerin bazı değişkenlere göre duygusal zekâ düzeyleri ve psikolojik danışma öz yeterlikleri

Yapılan araştırmada öğrencilerin duygusal zekâ düzeylerinin cinsiyetlerine göre anlamlı düzeyde farklılık gösterdiği ortaya çımıştır. Yapılan analizler, kadın öğrencilerin erkek öğrencilere oranla duygusal zekâya ilişkin davranışlara daha çok sahip olduğunu göstermektedir. Duygusal zekâ ölçeğinin alt boyutları açısından da durum aynıdır. İşmen (2001) tarafından 255 üniversite öğrencisi üzerinde duygusal zeka 
ve problem çözme becerisi arasındaki ilişkiyi inceleyen çalışmada da benzer sonuçlar elde edilmiş, duygusal zekanın cinsiyete göre farklılaştığı belirlenmiştir. Yurt dışında yapılan bazı çalışmalarda da (Ciarrochi, Chan, ve Bajgar, 2001; Mayer, 2001) benzer sonuçlar alındığ1 görülmektedir. Bu sonuçlara göre kadınların duygusal davranma, duyguları anlama ya da kullanma gibi davranışları erkeklere oranla daha iyi yaptıkları söylenebilir. Aksoy ve Diken (2009) tarafından yapılan çalışmada ise, rehber öğretmenlerin, özel eğitim öz yeterlikleri cinsiyete göre anlamı bir farklılık göstermemiştir. Konuyla ilgili yapılan çalışmaların çoğunda (Cora, 1997; Coşgun ve Ilgar, 2004; Özgün, 2007) cinsiyetle öz yeterlik arasında istatistiksel olarak anlamlı bir ilişki bulunmazken, kadınların erkeklere oranla daha yüksek öz yeterlik düzeyine sahip olduğunu belirten çalışmalar da (Coladarci \& Breton, 1997) bulunmaktadır.

Çalışmaya iki bölüm (PDR ve Psikoloji) dâhil edilmiştir. Öğrencilerin bölümlerine göre psikolojik danışma öz yeterlik düzeylerinin istatistiksel olarak farklılaşmadığı ortaya çıkmıştır. Ancak öğrencilerin duygusal zekâ ve alt boyutlarına ilişkin düzeylerinin öğrenim gördükleri bölümlere göre farklılık gösterdiği gözlenmiştir. Toplam duygusal zeka ve alt boyutlarında PDR öğrencilerinin ortalamalarının Psikoloji bölümü öğrencilerinin ortalamalarından daha yüksek bulunmuştur.

Öğrencilerin psikolojik yardım alıp almamalarına göre sadece duygusal zeka alt boyutlarından duyguların kullanımı alt boyutunun farklılık gösterdiği ortaya çıkmıştır. Duyguların kullanımı alt boyutunda psikolojik yardım almayan öğrencilerin ortalama puanlarının alanlardan daha yüksek olduğu görülmektedir. Öğrencilere gereksinim duydukları psikolojik danışmayı eğitim sürecinin her aşamasında yapabilecek bir sistem kurulmalıdır.

Öğrencilerin bölümlerini isteyerek seçip seçmemelerine göre duygusal zekâ ve psikolojik danışma öz yeterlik davranışlarına sahip olma düzeylerinin anlamlı bir şekilde farklılaştı̆̆ ortaya çıkmıştır. Bu analizde de bölümlerini isteyerek seçen öğrencilerin ortalamalarının kısmen isteyerek gelen öğrencilerle seçmek zorunda kalan öğrencilerin ortalamalarından daha yüksek bulunmuştur. Bölümlerini isteyerek seçen öğrencilerin psikolojik danışma öz yeterlik ve duygusal zekâ 
davranışlarına daha çok sahip olduğu ifade edilebilir. Bu durumda öğrencilere özellikle meslek seçimlerinde doğru rehberlik edilmeli, öğrencinin ilgi ve yeteneğine göre bir mesleğe yönlendirilmelidir.

Öğrencilerin öğrenim gördükleri bölümden memnuniyet düzeylerine göre yapılan analiz sonucunda, psikolojik danışma öz yeterlik düzeyleri ve alt boyutlarında gruplar arasında farklılık ortaya çımıştır. Bölümlerinden memnun olan öğrencilerin psikolojik danışma öz yeterlik davranışlarına daha çok sahip olduğu görülmektedir. Duygusal zekâ düzeyleri ile ilgili yapılan analizde ise, toplam duygusal zekâ ve İyimserlik - ruh halinin düzenlenmesi alt boyutunda istatistiksel olarak anlamlı farklılık ortaya çıkarken, duyguların kullanımı ve değerlendirilmesi alt boyutlarında gruplar arasında bir farklılık bulunmamıştır. Bu ölçekte de bölümlerinden memnun olan öğrencilerin puanları diğer iki gruptan fazla bulunmuştur.

\section{Öğrencilerin duygusal zekâ ve psikolojik danışma öz yeterlik düzeyleri arasındaki ilişki durumu}

Araştırmada her iki değişkenin ele alınmasının sebebi, duygusal zekâya ilişkin becerilerin psikolojik danışma öz yeterlik düzeyini etkileyeceği varsayımından dolayıdır. Sonuç olarak her iki değişken arasındaki ilişki incelendiğinde, öğrencilerin duygusal zekâ ve psikolojik danışma öz yeterlik düzeyleri arasında anlamlı düzeyde bir ilişkinin olduğu gözlenmiştir. Elde edilen verilerin analizi sonunda, duygusal zeka düzeylerinin öz yeterlilik düzeylerini pozitif etkilediği sonucuna ulaşılmıştır. Elde edilen bulguların da istatistiksel olarak anlamlı oldukları sonucuna ulaşılmıştır. Kullanılan regresyon modelinin elde edilen veriler ile uyumlu olduğu görülmüştür. Bağımsız değişkenleri kullanarak bağımlı değişkenlerin oluşma düzeyleri istatistiksel olarak tahmin edilebilir. İyi bir psikolojik danışmanın yetişebilmesi, bireylerin yaşama daha iyi uyum sağlayabilmesi ve sorunlarla baş edebilmesinin onun duygusal zekasını geliştirmekten geçtiği gerçeğinden hareketle, ana sınıfından itibaren öğrencilerin duygusal zekalarını geliştirecek özellikle yaparak öğrenme, birlikte çalışma, grup çalışması gibi etkinliklerin programlara ağırlıklı olarak konulmasında yarar vardır. 
EXTENDED ABSTRACT

\title{
Examination of Emotional Intelligence and Psycho- logical Counseling Self-Sufficiency of Psychology Education Students
}

\author{
* \\ Mustafa Durmuşçelebi / Şaban Karayağız \\ Erciyes University/ Nuh Naci YazganUniversity
}

Twenty first century has rapidly and thoroughly transformed the world and this trend is still on the go. Such a drastic change also effected "mind is superior" perspective. Especially in the Christian world, mindemotion conflict has been made since the ancient Greek and the mind has always been winner of the competition because dominant understanding was that emotions could hurt human being life. Since the 1990s, studies in the field of psychology and even 1960s liberty ideas were unable to change this result. So, supremacy of the mind remained until 2000s. Recent studies revealed that emotion cannot be separated from the mind and it serves a vital significance for people.

Studies also showed that emotional intelligence affects human quality of life because it helps us to deal with the problems and struggles we face in life such as problem solving, leadership, performance, success, satisfaction. The 'self-efficacy' concept is also an important skill for individuals to demonstrate a certain performance, to organize the necessary activities, to cope with situations successfully. Such attempts help people to deal with harshness of the world. Individuals could get psychological help in order to cope with life problems that they couldn't solve by themselves. The self-efficacy of psychological counseling is related to how the individual (counselor) meets demands of their patients. The competence of consultant may be considered as the perception of the effectiveness of the assistance to the patients. The purpose of this study was to investigate relationship between college students' emotional intelligence and phycological selfefficacy in the departments of Psychology and Guidance and 
Psychological Counseling programs. In this context, the following research questions were identified:

1. What are the students' self-efficacy levels of emotional intelligence and counseling?

2. Does their emotional intelligence and counseling self-efficacy levels differs based on;

a) Gender,

b) The majors,

c) Whether chosed their major willingly,

d) Satisfaction levels in their major,

e) Whether they receive psychological help?

3. Is there any significant relationship between emotional intelligence and psychological self-efficacy scores of the students.?

4. To what extend do the psychological counseling self-efficacy effect emotional intelligence?

The study population consisted of the students in Psychology and Guidance and Psychological Counseling and Psychology programs. Sample group were purposefully selected at a public and private colleges in Kayseri. Senior and Junior students were asked to volunteer in the study in order to explore their psychological counseling skills and emotional intelligence levels towards graduation.

In order to collect the necessary data, a personal information form, an emotional intelligence scale and a self-efficacy scale were handed to the participants. Emotional Intelligence Scale was developed by Schutte et al. (1998). It was based on the theoretical basis of the 33-item Emotional Intelligence Scale. It was modified by Austin et al. (2004) and included 41 items, 20 are positive and 21 negative statements. Psychological Counseling Self-Efficacy Scale was developed by Lent et al. (2003) in order to measure psychological counseling self-efficacy levels of counselors. The scale consists of 3 factors and 41 items.

Aligned with the research questions, statistical results (percentage, frequency, average, etc.), correlation between the variables were utilized to calculate the correlation; t-test and f-test were used to uncover differences between the independent variables. Pearson product-moment correlation coefficient was used to determine the relationship between the 
two dependent variables, emotional intelligence and psychological counseling self-efficacy levels.

Similar to previous studies, students' perceived emotional intelligence and psychological counseling self-efficacy levels were found above the average scores. As the previous researches expressed, emotional intelligence is related to many variables such as critical thinking, problem solving, coping with stress, leadership and social skill levels, and positively affects the individual's skills.

In the current investigation, it was achieved that emotional and psychological counseling self-efficacy levels of the students differed significantly according to their gender, whether they chose their departments willingly, and whether they were satisfied with their major. It also showed that that there exists a significant relationship between emotional intelligence and psychological counseling self-efficacy levels. Moreover, it was concluded that emotional intelligence level affects positively self-efficacy level.

Based on the findings obtained in this study, it is useful to facilitate students especially starting from kindergarten with more activities such as collaborative working, problem solving and learning by doing.

\section{Kaynakça/References}

Aksoy, V., ve Diken, İ. H. (2009). Rehber öğretmenlerin özel eğitimde psikolojik danışma ve rehberliğe ilişkin öz yeterlik algılarının incelenmesi. İlköğretim Online, 8(3), 709-719, 2009., 8(3), 709-719. 9 15, 2018 tarihinde http://ilkogretim-online.org.tr adresinden alınd 1

Arıcıoğlu, A. (2002). Yönetsel başarının değerlemesinde duygusal zekanın kullanımı. Akdeniz İktisadi İdari Bilimler Fakültesi Dergisi, 4, 24-42.

Ashforth, B. E., ve Humphrey, R. H. (1995). Emotion in the Workplace: A Reappraisal. Human Relations, 48(2), 97-125. doi:10.1177/001872679504800201

Ashkanasy, N., ve Daus, C. (2002). Emotion in the workplace: the new challenge for managers. Academy of Management Executive, 16(1), 76-86. 
Aslan, Ş., ve Güzel, Ş. (2018). Duygusal zeka, problem odaklı stresle başa çıkma, iyileşme ve duygusal tükenme ilişkileri. Yönetim Bilimleri Dergisi/Journal of Administrative Sciences, 16(31), 59-82.

Balcı, A. (2001). Sosyal bilimlerde araştırma. Ankara: Pegem Yayıncılık.

Bandura, A. (1986). Social Foundations of Thought and Action: A Social Cognitive Theory. Englewood Cliffs, NJ: Prentice-Hall Inc.

Boyatzis, R. E., Stubbs, E. C., ve Taylor, S. N. (2002). Learning cognitive and emotional intelligence competencies through graduate management education. Academy of Management Learning and Education, 1, 150-162.

Bülbüloğlu, A. (2001). Duygusal zeka kuramı. Trabzon: Karadeniz Teknik Üniversitesi.

Caudran, S. (1999). The Hard Case for Soft Skills. Workforce, 7(78), 60-67.

Ciarrochi, J., Chan, A., ve Bajgar, J. (2001). Measuring Emotional Intelligence in Adolescents. Personality and Individual Differences, 31(7), 1105-1119.

Coladarci, T., ve Breton, W. A. (1997). Teacher efficacy, supervision, and the special education resource-room teacher. The Journal of Educational Research, 90(4), 230-239. 9 17, 2018 tarihinde https://www.tandfonline.com/doi/abs/10.1080/00220671.1997.105 44577 adresinden alınd 1

Cora, N. (1997). Zihin engellilerin eğitimleri alannda çalışan öğretmenlerin yeterlilik düzeylerinin belirlenmesi. Bolu: Abant İzzet Baysal Üniversitesi Sosyal Bilimler Enstitüsü. 6 24, 23 tarihinde https://tez.yok.gov.tr/UlusalTezMerkezi/tarama.jsp adresinden alind 1

Coşgun, S., ve Ilgar, M. Z. (2004 ). Rehberlik ve psikolojik danışmanlık deneyimi çalışmalarının adayların öz yeterlik algılarına etkisi. XIII. Ulusal Eğitim Bilimleri Kurultayı. Malatya: İnönü Üniversitesi.

Dutoğlu, G., ve Tuncel, M. (2008). Aday öğretmenlerin eleştirel düşünme eğilimleri ile duygusal zeka düzeyleri arasındaki ilişki. Abant İzzet Baysal Üniversitesi Ĕ̆tim Fakültesi Dergisi, 8(1), 11-32.

Güçlü, M. (2017). Örgütsel iletişim: Eğitim kurumlarındaki yeri ve önemi açısından bir değerlendirme, OPUS-Uluslararası Toplum Araştırmaları Dergisi, 7(13), 854-870. 
İşmen, A. E. (2001). Duygusal zeka ve problem çözme. M.Ü. Atatürk Ĕ̆itim Fakültesi Ĕ̆itim Bilimleri Dergisi(13), 111-124.

Karabulutlu, E. Y., Yılmaz, S., ve Yurttaş, A. (2011). Öğrencilerin duygusal zeka düzeyleri ile problem çözme becerileri arasındaki ilişki. Psikiyatri Hemşireliği Dergisi - Journal of Psychiatric Nursing, 2(2), 75-79.

Larson, L. M., ve Daniels, J. A. (1998). Review of the counseling selfefficacy literature. Counseling Psychologist., 26(2), 179-218.

Law, K. S., Wong, C., ve Song, L. J. (2004). The construct and criterion validity of emotional intelligence and its potential utility for management studies. Journal of Applied Psychology, 89, 783-496.

Mayer, J. (2001). Emotional intelligence and giftedness. Roeper Review, 23(3), 131-137.

Orel, F. D., ve Yavuz, M. C. (2003). Rekreasyonel turizmde müşteri potansiyelinin belirlenmesine yönelik bir pilot çalışma. http://dergipark.ulakbim.gov.tr/cusosbil/article/viewFile/5000000965/5 000001656, 61-76.

Özgün, M. S. (2007). Okul psikolojik danışmanlarının kişilik özellikleri ile mesleki yetkinlik beklentileri arasndaki ilişkinin incelenmesi. Adana: Çukurova Üniversitesi Sosyal Bilimler Enstitüsü. 8 5, 2018 tarihinde https://tez.yok.gov.tr/UlusalTezMerkezi/tarama.jsp adresinden alınd 1

Planalp, S., ve Fitness, J. (1999). Thinking/feeling about social and personal relationship. Journal of Social and Personal Relationships, 16(6), 731-750.

Salovey, P., ve Mayer, J. D. (1990). Emotional intelligence: Imagination, Cognition and Personality. 6 22, 2018 tarihinde Yale Center for Emotional Intelligence: http://ei.yale.edu/publication/emotionalintelligence-5/ adresinden alınd 1

Schwarz, T. (2000, 05 31). How do you feel? 06 22, 2018 tarihinde Fast Company: https://www.fastcompany.com/40080/how-do-youfeel adresinden alınd 1

Ural, A. (2001). Yöneticilerde duygusal zekanın üç boyutu. Dokuz Eylül Üniversitesi Sosyal Bilimler Enstitüsü Dergisi, 3(2), 209-219. 
Yurdakavuştu, Y. (2012). Illköğretim öğrencilerinde duygusal zeka ve sosyal beceri düzeyleri. İzmir: Dokuz Eylül Üniversitesi Eğitim Bilimleri Enstitüsü. 9 17, 2018 tarihinde https://tez.yok.gov.tr/UlusalTezMerkezi/tezSorguSonucYeni.jsp adresinden alındı

\section{Kaynakça Bilgisi / Citation Information}

Durmuşçelebi, M. ve Karayağız, Ş. (2018). Psikoloji eğitimi alan öğrencilerin duygusal zekâ ve psikolojik danışma öz-yeterliklerinin incelenmesi. OPUS-Uluslararası Toplum Araştırmaları, 9(16), 79-108. DOI: 10.26466/opus. 460750 